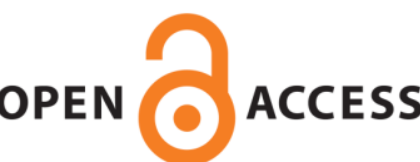

UWS Academic Portal

\title{
Assessing the impacts of the introduced channel catfish lctalurus punctatus using the comparative functional response approach
}

Faria, Larissa; Alexander, Mhairi E.; Vitule, Jean R.S.

Published in:

Fisheries Management and Ecology

DOI:

$10.1111 /$ fme. 12353

Published: 16/11/2019

Document Version

Peer reviewed version

Link to publication on the UWS Academic Portal

Citation for published version (APA):

Faria, L., Alexander, M. E., \& Vitule, J. R. S. (2019). Assessing the impacts of the introduced channel catfish Ictalurus punctatus using the comparative functional response approach. Fisheries Management and Ecology, 26(6), 570-577. https://doi.org/10.1111/fme.12353

\section{General rights}

Copyright and moral rights for the publications made accessible in the UWS Academic Portal are retained by the authors and/or other copyright owners and it is a condition of accessing publications that users recognise and abide by the legal requirements associated with these rights.

Take down policy

If you believe that this document breaches copyright please contact pure@uws.ac.uk providing details, and we will remove access to the work immediately and investigate your claim. 
"This is the peer reviewed version of the following article: Faria, L., Alexander, M. E., \& Vitule, J. R. S. (2019). Assessing the impacts of the introduced channel catfish Ictalurus punctatus using the comparative functional response approach. Fisheries Management and Ecology, which has been published in final form at https://doi.org/10.1111/fme.12353. This article may be used for noncommercial purposes in accordance with Wiley Terms and Conditions for Use of Self-Archived Versions."

https://authorservices.wiley.com/author-resources/Journal-Authors/licensing/self-archiving.html 


\section{Assessing the impacts of the introduced channel catfish Ictalurus punctatus using \\ 2 the Comparative Functional Response approach}

\section{Abstract}

4 In the metric "Relative Impact Potential” (RIP), the functional response (FR) of a non-

5 native species can be compared to that of a native analogue and combined with the species

6 abundance to predict its environmental impact. Here, using the River Guaraguaçu (Brazil)

7 as a case study, this methodology was implemented to identify the impacts of the non-

8 native channel catfish Ictalurus punctatus compared to a native species Rhamdia quelen

9 towards small prey fish. Both species exhibited Type II FRs, however handling times

10 were lower for $I$. punctatus, resulting in a greater maximum feeding rate in this species.

11 Consequently, an RIP $>1$ was found, indicating that $I$. punctatus represents a superior

12 impact to prey when compared to its native analogue. These results demonstrate that $I$.

13 punctatus is a potential threat to small endangered fish species. Therefore, policies to

14 avoid escapes from aquaculture should be created and the abundance of I. punctatus

15 controlled.

16 Keywords

17 alien species, aquaculture, fish, freshwater, management, Relative Impact Potential 
The introduction of non-native species to novel regions is one of the main drivers of species extinction and is considered the second major cause of global biodiversity loss after habitat destruction (Bellard, Cassey \& Blackburn, 2016; Clavero \& García-Berthou, 2005; Vitousek, D’Antonio, Loope \& Westbrooks, 1996). Predation by non-native species can devastate native prey populations as non-native predators are often more efficient consumers of resources compared to their native counterparts (Paolucci, MacIsaac \& Ricciardi, 2013; Salo, Korpimäki, Banks, Nordström \& Dickman, 2007; Simberloff \& Vitule, 2014). Compounding this, native prey often do not exhibit effective anti-predator behaviour due to a lack of shared evolutionary history with the new predator (Cox \& Lima, 2006). These mechanisms can explain the establishment success of nonnative predators and their negative impact in the recipient community (Gallardo, Clavero, importance for conservation of biodiversity, although there is no agreed standard methodology for doing so (Kumschick et al., 2015; Parker et al., 1999; Ricciardi, Hoopes, Marchetti \& Lockwood, 2013). The comparative functional response (CFR) has been proposed as an approach that “can unify invasion ecology” (Dick et al., 2017a), providing a trait-based methodology for measuring resource-use interactions of non-native species as a means of predicting their potential ecological impact. The CFR approach is based on the comparison of the functional response (FR) of non-native and trophically analogous native species, where the difference in the magnitude of the FR can predict and quantify the relative impacts of the non-native species (Dick et al., 2014). 
A FR is defined as the relationship between consumption rate and resource density (Holling, 1959b). There are three types of FR: Type I - an increasing linear relationship between resource density and consumption until a threshold of satiation; Type II - a decelerating rate of consumption that reaches an asymptote at higher densities; and Type III - an S-shaped curve where the consumption rate first accelerates at low densities and then decelerates towards satiation (Holling, 1959b). The FR type of the predator can have direct effects on the stability of the prey population, for instance Type II FR has destabilising effects with high consumption at low densities, whereas Type III has stabilising effects with a refuge of predation at low densities (Oaten \& Murdoch, 1975; Sinclair et al., 1998). As FRs measure the per capita effect of a non-native species, it can be combined with the abundance of the species in the field, in a metric called the Relative Impact Potential (RIP), to enhance the predictive power of this approach (Dick et al., 2017b).

A native to North America, the channel catfish (Ictalurus punctatus Rafinesque, 1818) has been introduced worldwide for aquaculture and sport fishing purposes (CABI, 2019). The species was first introduced in Brazil in 1971 and, having potentially escaped accidentally from aquaculture cages (Orsi \& Agostinho, 1999; Welcomme, 1988), it is now widely found in Brazilian water bodies (Cruz-Spindler et al., 2012; Ota, Message, Graça \& Pavanelli, 2015; Zanatta et al., 2010). As a non-native species, I. punctatus is a potential threat to local fish assemblages through competition and predation of native species (e.g. Matsuzaki et al., 2011; Townsend \& Winterbourn, 1992; Troca \& Vieira, 2012). For example, the decline and extinction of species, such as the razorback sucker Xyrauchen texanus, in communities invaded by I. punctatus has been reported (CABI, 2019). Additionally, I. punctatus demonstrates high rates of dispersal, which is aided by its ability to adapt to a wide range of habitats (Olden \& Poff, 2005). 

to assess the potential impacts of the invasive I. punctatus in a highly-diverse river in Brazil, the River Guaraguaçu. The abundance of the species is not constantly monitored, but there are reports about the establishment of this species in the river basin, as well as, in other basins of the Paraná State (Vitule, Umbria \& Aranha, 2005; Vitule, 2008). Based on the species traits and invasion history of I. punctatus (Gutierre, Vitule, Freire \& Prodocimo, 2014; Tatarenkov, Barreto, Winkelman \& Avise, 2006; Townsend \& Winterbourn, 1992; Wellborn, 1988), and considering its taxonomic distinctiveness within the recipient community (Ricciardi \& Atkinson, 2004), the likely impact of $I$. punctatus on native species and ecosystems is through an elevated consumption of small stream fishes.

To address the paucity of research on non-native species impacts in South American countries (Bellard \& Jeschke, 2016; Speziale, Lambertucci, Carrete \& Tella, 2012; Vitule, Freire, Vazquez, Nuñez \& Simberloff, 2012), the present study aims to enhance the understanding of the impacts of introduced predators in the Neotropical region, where biodiversity is both rich and threatened (Lowry et al., 2013; Myers, Mittermeier, Mittermeier, da Fonseca \& Kent, 2000).

\section{$2 \quad$ Methods}

\section{$2.1 \quad$ Species used}

87 Ictalurus punctatus is a nocturnal forager that uses a variety of habitats with preference 88 for shallow warm waters (Bayley \& Harrison, 1948; Braun \& Phelps, 2016; Jordan, 89 Neumann \& Schultz, 2004), detecting food using olfactory and visual cues (Becker, 1983). Young I. punctatus feed mainly on insects, but adults are usually omnivorous and

91 prey also on fish (Bailey \& Harrison, 1948; Braun \& Phelps, 2016; Hill, Duffy \& 
Thompson, 1995; Tyus \& Nikirk, 1990). The species has opportunistic behaviour and is generalist, preying on a wide range of available resources in non-native regions (Endo et al., 2015; Haubrock et al., 2018).

The FRs of the non-native channel catfish I. punctatus were compared to a native consumer, the South American silver catfish Rhamdia quelen (Quoy \& Gaimard, 1824), which is a benthic species widely distributed in lakes, reservoirs and rivers of Central and South America (Gomes, Golombieski, Gomes \& Baldisserotto, 2000; Silfvergrip, 1996). There are few studies on the biology of $R$. quelen, which like I. punctatus is representative of the Siluriformes and is generally described as nocturnal and omnivorous when mature (Bailey \& Harrisson, 1948; Gomes et al., 2000; Goudie, Davis \& Simco, 1983). Adults of $R$. quelen are considered generalists, feeding on fish, crustaceans, insects, vegetation and organic detritus (Guedes, 1980; Meurer \& Zaniboni Filho, 1997). Ictalurus punctatus and $R$. quelen have many similarities in their anatomic digestive systems and diet (Piedras, Pouey \& Moraes, 2006) which make $R$. quelen an appropriate resident comparator for I. punctatus in the FR experiments described here.

Both species also spawn in the spring, with temperature an important factor in reproduction (Becker, 1983; Gomes et al., 2000). Rhamdia quelen has low fecundity rates and do not present parental care (Gomes et al., 2000). Females of I. punctatus have around 8,000 eggs per kg body weight and males guard the eggs during a period of incubation of 5 to 10 days (Becker, 1983). Ictalurus punctatus reaches sexual maturity at 300-375 mm in total length (TL), whereas $R$. quelen generally matures at 134-175 mm TL (Gomes et al., 2000; Jackson, 2004; Shephard \& Jackson, 2005).

Blue tetra Mimagoniates microlepis (Steindachner, 1877), a congeneric of the locally and nationally threatened M. lateralis (Abilhoa \& Duboc, 2004; Rosa \& Lima, 2008; MMA, 2014), is abundant in natural water bodies and was used as prey in 
experimental trials. Both Mimagoniates species are sympatric and are representatives of

118 Glandulocaudinae, which is characterised by small stream fishes (Braga, Braga, \& Vitule, 2013; Menezes \& Weitzman, 2009). Mimagoniates lateralis is the smallest species of the genus, reaching maximum 40 mm standard length (Menezes \& Weitzman, 2009; Rosa \& Lima, 2008).

\subsection{Experimental design}

123 For the experimental protocol (Figure S1), which was approved by the Ethics Commission on the Use of Animals of the Biological Sciences Department of the Federal University of Paraná (CEUA/BIO UFPR - Certificate nº1027), juveniles of predator fish species (I. punctatus and R. quelen) were obtained in local aquaculture farms and stored in tanks of $300 \mathrm{~L}$ in the lab. Each species was kept in a different tank with constant aeration and filtration for acclimation during 30 days. Prey fish were collected in the field using fishing nets and kept in an $80 \mathrm{~L}$ aquarium, with constant aeration and filtration, and were also acclimated for 30 days. The temperature in the lab was kept at $22-26^{\circ} \mathrm{C}$ under a natural light regime. During the acclimation period predators were fed every $48 \mathrm{~h}$ with sausage to standardise prior experience. with constant aeration. Individuals of predator species were randomly selected one day prior to use and placed in the experimental aquariums for $24 \mathrm{~h}$ acclimation. Predators $(n$ = 9 per species) were size-matched with respect to total length ( $R$. quelen: $16.39 \mathrm{~cm} \pm$ 1.15 and $I$. punctatus: $16.83 \mathrm{~cm} \pm 2.14$; Students' $t$-test, $t=-0.55, \mathrm{df}=16, p=0.59$ ). Each predator specimen was reused in two more trials with different initial densities. After the acclimation period, they were held without food for $72 \mathrm{~h}$ to standardise hunger levels.

140 Predators were then presented with the prey at five initial densities $(2,5,10,20$, and 30 individuals), with five replicates per density. Prey were also size matched with respect to 
142 total length by visual selection $(\approx 3 \mathrm{~cm})$. Experiments were initiated at 14:00 and prey consumption was recorded after $24 \mathrm{~h}$. Controls were three replicates of each initial density

144 of prey in the absence of predators.

145

146

147

\subsection{Data analysis}

The FR type was determined from a logistic regression of prey density by the proportion of consumed prey, as proposed by Juliano (2001). A negative first order term indicates a Type II FR, whereas a positive first order term followed by a negative second order term indicates a Type III FR (Pritchard, Paterson, Bovy \& Barrios-O’Neill, 2017). The FR curves and the parameters attack rate $(a)$ and handling time $(h)$ were modelled using Maximum Likelihood Estimation (Bolker, 2008) with the Rogers' (1972) random predator equation that considers the depletion of prey without replacement along the experimental period:

$$
\mathrm{N}_{\mathrm{e}}=\mathrm{N}_{0}\left\{1-\exp \left[a\left(\mathrm{~N}_{\mathrm{e}} h-\mathrm{T}\right)\right]\right\}
$$

where $\mathrm{N}_{\mathrm{e}}$ is the number of prey consumed, $\mathrm{N}_{0}$ is the initial density of prey, $a$ is the attack rate, $h$ is the handling time and $\mathrm{T}$ is the experimental period, given in days. The attack rate $(a)$ is the instantaneous capture rate, i.e. the rate at which the consumer encounters resource items per unit of resource density; and the handling time $(h)$ is the time spent capturing and consuming the prey item (Brose, 2010; Holling, 1959a; Jeschke, Kopp \& Tollrian, 2002). The $h$ was used to estimate the maximum feeding rate $(1 / h T)$, which represents the FR curve asymptote. To compare the FR of each species, the parameters $a$ and $h$ were compared between predators using the indicator variables method, as the following equation:

$$
\left.0=\mathrm{N}_{0}-\mathrm{N}_{0} \exp \left\{[a+\mathrm{D} a(\mathrm{j})]\{h+\mathrm{Dh}(\mathrm{j})]\left(\mathrm{N}_{\mathrm{e}}\right)-\mathrm{T}\right\}\right\}-\mathrm{N}_{\mathrm{e}}
$$


where $\mathrm{j}$ is an indicator variable that takes value 0 for $R$. quelen and 1 for $I$. punctatus. The parameters $\mathrm{D} a$ and Dh estimate the differences between the predators in the value of the parameters $a$ and $h$, respectively. If these parameters are significantly different from zero, then the two species differ significantly in the corresponding parameters (Juliano, 2001). To visualise the uncertainty around the fitted functional responses, 95\% confidence intervals were constructed by bootstrapping $(n=2000)$ data around FR curves. If confidence intervals do not overlap, then it can be stated that species FRs differ (Paterson et al., 2015). Analyses were carried in R v. 3.4.1 (R Core Team, 2015) using the 'frair' package (Pritchard et al., 2017) at 0.05 significance.

The Relative Impact Potential (RIP) metric was calculated using the following equation, according to proposed by Dick et al., 2017b:

$$
\text { RIP }=\frac{\text { FR non-native }}{\text { FR native }} X \frac{\mathrm{AB} \text { non-native }}{\mathrm{AB} \text { native }}
$$

where FR is the estimated maximum feeding rate $(1 / h \mathrm{~T})$ and $\mathrm{AB}$ is the field abundance/biomass of the species. When RIP $<1$, the non-native species is predicted to have less impact than the native equivalent; when RIP $=1$, there is no impact above that driven by native equivalents; whereas RIP > 1 indicates a likely non-native ecological impact (Dick et al., 2017b). Data of total abundance and biomass were taken from literature, from samples collected in River Guaraguaçu using a variety of fishing gears (Vitule, 2008) (Table S1). As data from different methods of capture and of different fishing efforts were compiled (Table S1), the capture per unit effort (CPUE) was calculated to standardise these differences. This was the number of fishes captured divided by the number of fish hooks or area of gill nets, multiplied by fishing effort in hours. 
None of the prey fish died in any of the control replicates, therefor prey mortality in the experimental trials was attributed to predation. Both species obtained a negative firstorder term from logistic regressions, indicating a Type II FR (Table 1, Figure 1). Parameter estimates of the FR model were all statistically significant (Table 1). The attack rate did not differ between species ( $\mathrm{D} a=-0.646, \mathrm{z}=-0.447, p=0.655)$, but the handling time was significantly lower for I. punctatus ( $\mathrm{D} h=0.053, \mathrm{z}=2.209, p<0.05$ ), and thus a higher maximum feeding rate was obtained (Table 1).

The RIP calculated using field data on total abundance did not demonstrate a greater impact of the non-native species (RIP $<1$, Table 2). Considering biomass, the impact of I. punctatus was found to be similar to the native species $R$. quelen (RIP $\approx 1$,

Table 2). However, using CPUE data, I. punctatus was found to have a greater impact (RIP > 1, Table 2).

\section{$4 \quad$ Discussion}

202

Both predator species in the present study demonstrated a Type II FR when exposed to M. microlepis. Most, if not all, of the prey were consumed at low densities, which suggests that in open waters this could lead to destabilising effects on the local population (Holling, 1959a; Murdoch \& Oaten, 1975; Sinclair et al., 1998). A Type II FR may therefore pose a greater concern in open waters, where endangered, such as M. lateralis, are often found to exist in small populations (IUCN, 2012; Sinclair et al., 1998). ecological impact to native small fish prey, and it is possible that other small-bodied endangered fish species suffer predation pressure from I. punctatus in a similar manner as M. microlepis. Despite the overlap of FR curves of $I$. punctatus and its native 
exerts a greater predation pressure on $M$. microlepis, with a significant lower handling time, and therefore a higher maximum feeding rate. Lower $h$ and consequently higher $1 / h \mathrm{~T}$, due to faster rates in processing prey, can explain the superior impact of invaders (Alexander, Dick, Weyl, Robinson \& Richardson, 2014). The lower handling time of $I$. punctatus (Table 1) may be due to differences in the resource acquisition ability of the species (Alexander et al., 2014). Ictalurus punctatus has taste buds across its body and within its barbels, which aid in perception of food and trigger feeding behaviour (Caprio et al., 1993; Valentincic \& Caprio, 1994). Ictalurus punctatus also has relatively larger eyes than other siluriform catfishes, which may facilitate visual predation in clean waters, such as of the experimental conditions (Davis, 1959). The similar FRs of I. punctatus and $R$. quelen towards the prey (Figure 1) also suggest that these species may have niche species seems to use the same strategy to find resources, as their barbels are sensitive to amino acids or hydrolysed proteins, which triggers feeding behaviour (Caprio, 1975; Broggi, 2014).

Ictalurus punctatus are less abundant than native $R$. quelen in the River Guaraguaçu, which suggests a lower relative predation impact than the native species. However, using standardised CPUE data, a different result emerged, with I. punctatus presenting a higher abundance (Table 2), and therefore a potentially greater impact than $R$. quelen. Using only the FR provides a modestly-powered predictor of non-native species impacts, because a low FR can be compensated by high abundance in the field (Laverty et al., 2017). The results obtained here, of a greater RIP using CPUE field data (Table 2), are sufficient to justify the need of management and control of I. punctatus population. Early interventions may be successful in avoiding non-native species impacts 
237 (Simberloff, 2003), and in the present case, the results provide evidence to motivate the

238 immediate action to manage I. punctatus at low population levels. Propagule pressure is widely believed to play a fundamental role on the successful establishment and permanency of non-native species, contributing to its continuous impact (Copp, Templeton \& Gozlan, 2007; Kolar \& Lodge, 2001; Ruesink, 2005). The juvenile $I$. punctatus used in these experiments were obtained from local aquaculture, which is recognised as the major pathway of introduction of I. punctatus and other freshwater invasive species (CABI, 2019; Casal, 2006; Gozlan, 2008; Naylor, Williams \& Strong, 2001). Ictalurus punctatus is among the most cultured freshwater fishes globally, and its global total production in 2016 reached 432,932 tons (FAO, 2018). There are many fish-farms in Paraná State that cultivate and sell young-of-the-year $I$. punctatus despite a legislation that classifies this species as Category I, which has its "transportation, breeding, release or translocation, cultivation, propagation, commercialization, donation or intentional acquisition prohibited by any means"

(Environmental Institute of Paraná, 2015). Despite this, the production of I. punctatus continues to increase, and the risk of escapes from aquaculture ponds is a constant threat in Neotropical streams, contributing to a high propagule pressure (Forneck, Dutra, Zacarkim \& Cunico, 2016; Lima Junior, Pelicice, Vitule \& Agostinho, 2012; Vitule, Freire \& Simberloff, 2009). This failed attempt to ban the introduction of I. punctatus in Paraná could be responsible for the declines in status of many endemic fishes (Lima Junior et al., 2018; Pelicice et al., 2017; Vitule et al., 2009). Therefore, the cultivation of the I. punctatus should be avoided in Paraná in order to reduce its spreading into natural water bodies.

Besides constant introductions of $I$. punctatus, the species' reproductive behaviour (guarders, nest spawners) is more specialised than that of $R$. quelen 
262 (nonguarders, open substratum spawners) (see Balon, 1975). The male I. punctatus guards the eggs until they hatch, a feature that may favour the establishment of the nonnative species in the field (Marchetti, Moyle \& Levine, 2004; Tatarenkov et al., 2006). Also, predation of $I$. punctatus by native fishes in the study region is unlikely due to the dorsal and pectoral spines of I. punctatus (Bosher, Newton \& Fine, 2006). In the present study, juveniles of similar body size were used, which contrasts natural populations. Predator body-size influences most aspects of feeding behaviour and there are allometric relationships between body size and the FR parameters, with increases in $a$ and decreases in $h$ as predator size increases (Brose, 2010; González-Suárez et al., 2011; Miller, Crowder, Rice \& Binkowski, 1992; Vucic-Pestic, Rall, Kalinkat \& Brose, 2010). In the case of the two study species, I. punctatus can reach larger adult sizes than $R$. quelen, as the first can be mature at size $300 \mathrm{~mm}$ TL and $R$. quelen is already mature at 175 mm TL (Gomes et al., 2000; Jackson, 2004; Shephard \& Jackson, 2005), which may lead to an increased per capita effect of the non-native species that could can be expected a greater per capita effect of adults of in the field. Furthermore, omnivores like I. punctatus tend to present a Type II FR when exposed to a single type of prey, and the presence of an alternative food source may therefore affect our results (Médoc, Thuillier \& Spataro, 2017; Murdoch \& Oaten, 1975). Indeed, alternative food availability has been shown to change FRs of amphipods, killer shrimp Dikerogammarus villosus and the freshwater shrimp Gammarus pulex, with the superior consumption of the invasive $D$. villosus disappearing when it was presented with an alternative nonanimal food (Médoc, Thuillier \& Spataro, 2017). 
The mean biomass of I. punctatus specimens captured in the River Guaraguaçu was more than twice of the native species and the RIP using biomass was $\approx 1$ (Table 2 ), which suggests that the impact of I. punctatus in the wild is greater than the native predator despite its lower abundance. Neither predator species nor size alone can predict consistently the FR type and its associated parameters, so both predator identity and size should be considered to assess fully the potential ecological impacts of a non-native species on invaded communities (Anderson, Linares, Dodson \& Semlitsch, 2016; Guo, Sheath, Amat Trigo \& Britton, 2016). complexity (Alexander, Dick, O’Connor, Haddaway \& Farnsworth, 2012; BarriosO’Neill, Dick, Emmerson, Ricciardi \& Macisaac, 2015), which in some cases can change the FR type and parameters. This can occur if habitat complexity acts as a refuge for prey in low density (Alexander, Kaiser, Weyl \& Dick, 2015) or contributes to predation of ambush predators, resulting in a higher consumption rate (Santos, García-Berthou, Hayashi \& Santos, 2013). This context-dependency factor may also be an important feature to be tested in the FR of I. punctatus, as the River Guaraguaçu has been invaded by the African signalgrass Urochloa arrecta, a macrophyte that increases habitat complexity (Michelan, Thomaz, Mormul \& Carvalho, 2010; Thomaz \& Cunha, 2010; Vitule, Umbria \& Aranha, 2006). importance to conservation efforts, because such data are needed in order to create plans for management and control of damaging species. The CFR approach and the RIP metric have been shown as an effective tool for predicting the impact of existing and emerging 
312 (Alexander et al., 2014; Dick et al., 2017a, 2017b; Laverty et al., 2017). Therefore, the

313 CFR approach is of particular usefulness in both developing and developed countries

314 because data on non-native fish impacts are lacking for most species. Whereas, data on

315 non-native species impacts are even more scarce in less developed regions, where the

316 number of potentially threatened endemic species is often high (Frehse, Braga, Nocera \&

317 Vitule, 2016; Lövei, Lewinsohn \& Network, 2012; Nuñez \& Pauchard, 2010; Vitule et 318 al., 2017).

319

320

321

322

323

\section{References}

Abilhoa, V., \& Duboc, L. F. (2004). Peixes. In S. B. Mikich \& R. S. Bérnils (Eds), Livro vermelho dos animais ameaçados de extinção no Estado do Paraná (pp. 581-677). Curitiba: Mater Natura e Instituto Ambiental do Paraná.

Alexander, M. E., Dick, J. T. A., O’Connor, N. E., Haddaway, N. R., \& Farnsworth, K. D. (2012). Functional responses of the intertidal amphipod Echinogammarus marinus: effects of prey supply, model selection and habitat complexity. Marine Ecology Progress Series, 468, 191-202.

Alexander, M. E., Dick, J. T. A., Weyl, O. L. F., Robinson, T. B., \& Richardson, D. M. (2014). Existing and emerging high impact invasive species are characterized by higher functional responses than natives. Biology Letters, 10, 2-6.

Alexander, M. E., Kaiser, H., Weyl, O. L. F., \& Dick, J. T. A. (2015). Habitat simplification increases the impact of a freshwater invasive fish. Environmental Biology of Fishes, 98, 477-486.

Anderson, T. L., Linares, C., Dodson, K. N., \& Semlitsch, R. D. (2016). Variability in functional response curves among larval salamanders: comparisons across species and size classes. Canadian Journal of Zoology, 94, 23-30.

Bailey, R. M., \& Harrison , H. M. (1948). Food habits of the southern channel catfish (Ictalurus lacustris punctatus) in the Des Moines River, Iowa. Transactions of the American 
Balon, E. K. (1975). Reproductive guilds of fishes: a proposal and definition. Journal of the Fisheries Research Board of Canada, 32, 821-864.

Barrios-O’Neill, D., Dick, J. T. A., Emmerson, M. C., Ricciardi, A., \& MacIsaac, H. J. (2015). Predator-free space, functional responses and biological invasions. Functional Ecology, 29, 377-384.

Becker, G. C. (1983). Fishes of Wisconsin. Madison: University of Wisconsin Press.

Bellard, C., Cassey, P., \& Blackburn, T. M. (2016). Alien species as a driver of recent extinctions. Biology Letters, 12, 20150623.

Bellard, C., \& Jeschke, J. (2016). A spatial mismatch between invader impacts and research publications. Conservation Biology, 30, 230-232.

Bolker, B. M. (2008). Ecological models and data in R. Princeton: Princeton University Press.

Bosher, B. T., Newton, S. H., \& Fine, M. L. (2006). The spines of the channel catfish, Ictalurus punctatus, as an anti-predator adaptation: an experimental study. Ethology, 112, 188-195.

Braga, R. R., Braga, M. R., \& Vitule, J. R. S. (2013). Population structure and reproduction of Mimagoniates microlepis with a new hypothesis of ontogenetic migration: implications for stream fish conservation in the Neotropics. Environmental Biology of Fishes, 96, 21-31.

Braun, A. P., \& Phelps, Q. E. (2016). Channel catfish habitat use and diet in the Middle Mississippi River. The American Midland Naturalist, 175, 47-54.

Broggi, J. A. (2014). Hidrolisado proteico de sardinha (Clupeidae) como atrativo alimentar para o jundiá (Rhamdia quelen). Master thesis, Universidade do Estado de Santa Catarina. 49 p.

Brose, U. (2010). Body-mass constraints on foraging behaviour determine population and foodweb dynamics. Functional Ecology, 24, 28-34.

CABI, 2019. Ictalurus punctatus [original text by C Engle]. In Invasive Species Compendium. Wallingford, UK: CAB International. www.cabi.org/isc.

Caprio, J. (1975). High sensivity of catfish taste receptors to amino acids. Comparative Biochemistry and Physiology B, 52, 247-251.

Caprio, J., Brand, J. G., Teeter, J. H., Valentincic, T., Kalinoski, D. L., Kohbara, J., ... Wegert, 
S. (1993). The taste system of the channel catfish: from biophysics to behavior. Trends in Neurosciences, 16, 192-197.

Casal, C. M. V. (2006). Global documentation of fish introductions: the growing crisis and recommendations for action. Biological Invasions, 8, 3-11.

Clavero, M., \& García-Berthou, E. (2005). Invasive species are a leading cause of animal extinctions. Trends in Ecology and Evolution, 20, 110.

Copp, G. H., Templeton, M., \& Gozlan, R. E. (2007). Propagule pressure and the invasion risks of non-native freshwater fishes in Europe: a case study of England. Journal of Fish Biology, 71 (Supplement D), 148-159.

Cox, J. G., \& Lima, S. L. (2006). Naiveté and an aquatic-terrestrial dichotomy in the effects of introduced predators. Trends in Ecology and Evolution, 21, 674-680.

Cruz-Spindler, S., Leal, M. E., Lehmann, P. C., \& Schulz, U. H. (2012). First record of the exotic channel catfish Ictalurus punctatus (Rafinesque 1818) (Siluriformes: Ictaluridae) in the Rio dos Sinos basin, RS, Brazil. Biota Neotropica, 12, 64-67.

Davis, J. (1959). Management of channel catfish in Kansas. Museum of Natural History Miscellaneous Publication, 21, 1-56.

Dick, J. T. A., Alexander, M. E., Jeschke, J., Ricciardi, A., MacIsaac, H. J., Robinson, T. B., ... Richardson, D. M. (2014). Advancing impact prediction and hypothesis testing in invasion ecology using a comparative functional response approach. Biological Invasions, 16, 735753.

Dick, J. T. A., Alexander, M. E., Ricciardi, A., Laverty, C., Downey, P. O., Xu, M., ... Shaw, R. H. (2017a). Functional responses can unify invasion ecology. Biological Invasions, 19, 1667-1672.

Dick, J. T. A., Laverty, C., Lennon, J. J., Barrios-O’Neill, D., Mensink, P. J., Britton, J. R., ... Caffrey, J. M. (2017b). Invader Relative Impact Potential: a new metric to understand and predict the ecological impacts of existing, emerging and future invasive alien species. Journal of Applied Ecology, 54, 1259-1267.

Endo, T., Kaneko, S., Igari, K., Kanou, K., Nakazato, R., Kamei, R., ... Hyakunari, W. (2015). 
Feeding characteristics of the channel catfish Ictalurus punctatus in the littoral zone of Lake Kitaura, Ibaraki Prefecture, Japan. Aquaculture Science, 63, 49-58.

FAO. (2018). FAO yearbook. Fishery and Aquaculture Statistics 2016. Rome: FAO.

Forneck, S. C., Dutra, F. M., Zacarkim, C. E., \& Cunico, A. M. (2016). Invasion risks by nonnative freshwater fishes due to aquaculture activity in a Neotropical stream.

Gallardo, B., Clavero, M., Sánchez, M. I., \& Vilà, M. (2016). Global ecological impacts of invasive species in aquatic ecosystems. Global Change Biology, 22, 151-163.

Gomes, L. C., Golombieski, J. I., Gomes, A. R. C., \& Baldisserotto, B. (2000). Biologia do jundiá Rhamdia quelen (Teleostei, Pimelodidae). Ciência Rural, 30, 179-185.

González-Suárez, M., Mugabo, M., Decencière, B., Perret, S., Claessen, D., \& Le Galliard, J. F. (2011). Disentangling the effects of predator body size and prey density on prey consumption in a lizard. Functional Ecology, 25, 158-165.

Goudie, C., Davis, K., \& Simco, B. (1983). Influence of the eyes and pineal gland on locomotor activity patterns of channel catfish Ictalurus punctatus. Physiological Zoology, 56, 10-17.

Gozlan, R. E. (2008). Introduction of non-native freshwater fish: is it all bad? Fish and Fisheries, 9, 106-115.

Guedes, D. S. (1980). Contribuição ao estudo da sistemática e alimentação de jundiás (Rhamdia spp) na região central do Rio Grande do Sul (Pisces, Pimelodidae). Master thesis, Universidade Federal de Santa Maria. 99 p.

Guo, Z., Sheath, D., Amat Trigo, F., \& Britton, J. R. (2016). Comparative functional responses of native and high-impacting invasive fishes: impact predictions for native prey populations. Ecology of Freshwater Fish, 26, 533-540.

Gutierre, S. M. M., Vitule, J. R. S., Freire, C. A., \& Prodocimo, V. (2014). Physiological tools to predict invasiveness and spread via estuarine bridges: tolerance of Brazilian native and 

Research, 65, 425-436.

Haubrock, P. J., Balzani, P., Johovic, I., Inghilesi, A. F., Nocita, A., \& Tricarico, E. (2018). The diet of the alien channel catfish Ictalurus punctatus in the River Arno (Central Italy). Aquatic Invasions, 13, 575-585.

Hill, T. D., Duffy, W. G., \& Thompson, M. R. (1995). Food-habits of channel catfish in Lake Oahe, South-Dakota. Journal of Freshwater Ecology, 10, 319-323.

Holling, C. S. (1959a). Some characteristics of simple types of predation and parasitism. The Canadian Entomologist, 91, 385-398.

Holling, C. S. (1959b). The components of predation as revealed by a study of small-mammal predation of the European pine sawfly. The Canadian Entomologist, 91, 234-261.

Jeschke, J., Kopp, M., \& Tollrian, R. (2002). Predator functional responses: discriminating

IUCN. (2012). IUCN Red List Categories and Criteria: Version 3.1. (2nd ed.). Gland, Switzerland and Cambridge, UK.

Jackson, D. C. (2004). Natural history and fisheries. In C. S. Tucker \& J. A. Hargreaves (Eds), Biology and culture of channel catfish (pp. 15-35). Amsterdam: Elsevier.

\section{Jeschke, J, Kopp, M., \& Tollian, R. (2002). Predator functional responses: discriminating} between handling and digesting prey. Ecological Monographs, 72, 95-112.

Jordan, S. M., Neumann, R. M., \& Schultz, E. T. (2004). Distribution, habitat use, growth, and condition of a native and an introduced catfish species in the Hudson River estuary. Journal of Freshwater Ecology, 19, 59-67.

Juliano, S. A. (2001). Nonlinear curve fitting. In S. M. Scheiner \& J. Gurevitch (Eds), Design and analysis of ecological experiments (pp. 178-196). Oxford: Oxford University Press.

Kolar, C. S., \& Lodge, D. M. (2001). Progress in invasion biology: predicting invaders. Trends in Ecology and Evolution, 16, 199-204.

Kumschick, S., Gaertner, M., Vilà, M., Essl, F., Jeschke, J., Pyšek, P., ... Winter, M. (2015). 
Latini, A. O., \& Petrere Jr., M. (2004). Reduction of a native fish fauna by alien species: an example from Brazilian freshwater tropical lakes. Fisheries Management and Ecology, 11, $71-79$.

Laverty, C., Green, K. D., Dick, J. T. A., Barrios-O’Neill, D., Mensink, P. J., Médoc, V., ... Gallagher, C. (2017). Assessing the ecological impacts of invasive species based on their functional responses and abundances. Biological Invasions, 19, 1653-1665.

Lima Junior, D. P., Magalhães, A. L. B., Pelicice, F. M., Vitule, J. R. S., Azevedo-Santos, V. freshwaters against the Aichi Biodiversity Targets. Ambio, 47, 427-440.

Lima Junior, D. P., Pelicice, F. M., Vitule, J. R. S., \& Agostinho, A. A. (2012). Aquaculture, politics and environment in Brazil: new proposals and old misconceptions. Natureza \& Conservação, 10, 88-91.

Lövei, G. L., Lewinsohn, T. M., \& the Biological Invasions in Megadiverse Regions Network (2012). Megadiverse developing countries face huge risks from invasives. Trends in Ecology and Evolution, 27(1), 2-3.

Lowry, E., Rollinson, E. J., Laybourn, A. J., Scott, T. E., Aiello-Lammens, M. E., Gray, S. M., ... Gurevitch, J. (2013). Biological invasions: a field synopsis, systematic review, and database of the literature. Ecology and Evolution, 3, 182-196.

Marchetti, M. P., Moyle, P. B., \& Levine, R. (2004). Invasive species profiling? Exploring the characteristics of non-native fishes across invasion stages in California. Freshwater Biology, 49, 646-661.

Matsuzaki, S. S., Takamura, N., Arayama, K., Tominaga, A., Iwasaki, J., \& Washitani, I. (2011). Potential impacts of non-native channel catfish on commercially important species in a Japanese lake, as inferred from long-term monitoring data. Aquatic Conservation: Marine and Freshwater Ecosystems, 21, 348-358.

Médoc, V., Thuillier, L., \& Spataro, T. (2017). Opportunistic omnivory impairs our ability to 
predict invasive species impacts from functional response comparisons. Biological Invasions, 20, 1307-1319.

480

481

482

Menezes, N. A., \& Weitzman, S. H. (2009). Systematics of the neotropical fish subfamily Glandulocaudinae (Teleostei: Characiformes: Characidae). Neotropical Ichthyology, 7, 295-370.

Meurer, S., Zaniboni Filho, E. (1997). Hábito alimentar do jundiá Rhamdia quelen (Pisces, Siluriformes, Pimelodidae), na região do alto rio Uruguai. Anais do XII encontro Brasileiro de ictiologia.

Michelan, T. S., Thomaz, S. M., Mormul, R. P., \& Carvalho, P. (2010). Effects of an exotic invasive macrophyte (tropical signalgrass) on native plant community composition, species richness and functional diversity. Freshwater Biology, 55, 1315-1326.

Miller, T. J., Crowder, L. B., Rice, J. A., \& Binkowski, F. P. (1992). Body size and the ontogeny of the functional response in fishes. Canadian Journal of Fisheries and Aquatic Sciences, 49, 805-812.

MMA. (2014). Portaria n 445, de 17 de dezembro de 2014. Peixes e Invertebrados Aquáticos Ameaçados. Ministério do Meio Ambiente.

(www.icmbio.gov.br/portal/portaldabiodiversidade/50-menu-biodiversidade/6706portarias-fauna-ameacada)

Murdoch, W. W., \& Oaten, A. (1975). Predation and population stability. Advances in Ecological Research, 9, 1-131.

Myers, N., Mittermeier, R. A., Mittermeier, C. G., da Fonseca, G. A. B., \& Kent, J. (2000). Biodiversity hotspots for conservation priorities. Nature, 403, 853-858.

Naylor, R. L., Williams, S. L., \& Strong, D. R. (2001). A gateway for exotic species. Science, 294, 1655-1656.

Nuñez, M. A., \& Pauchard, A. (2010). Biological invasions in developing and developed countries: does one model fit all? Biological Invasions, 12, 707-714.

Oaten, A., \& Murdoch, W. W. (1975). Switching, functional response, and stability in predatorprey systems. The American Naturalist, 109, 299-318. 
Olden, J. D., \& Poff, N. L. (2005). Long-term trends of native and non-native fish faunas in the American Southwest. Animal Biodiversity and Conservation, 28, 75-89.

Orsi, M. L., \& Agostinho, A. A. (1999). Introdução de espécies de peixes por escapes acidentais de tanques de cultivo em rios da Bacia do Rio Paraná, Brasil. Revista Brasileira de Zoologia, 16, 557-560.

Ota, R. R., Message, H. J., Graça, W. J. , \& Pavanelli, C. S. (2015). Neotropical siluriformes as a model for insights on determining biodiversity of animal groups. PLOS ONE, 10(7), 113.

Paolucci, E. M., MacIsaac, H. J., \& Ricciardi, A. (2013). Origin matters: alien consumers inflict greater damage on prey populations than do native consumers. Diversity and Distributions, 19, 988-995.

Parker, I. M., Simberloff, D., Lonsdale, W., Goodell, K., Wonham, M., Kareiva, P., ... Goldwasser, L. (1999). Impact: toward a framework for understanding the ecological effects of invaders. Biological Invasions, 1, 3-19.

Paterson, R. A., Dick, J. T. A., Pritchard, D. W., Ennis, M., Hatcher, M. J., \& Dunn, A. M. (2015). Predicting invasive species impacts: a community module functional response approach reveals context dependencies. Journal of Animal Ecology, 84, 453-463.

Pelicice, F. M., Azevedo-Santos, V. M., Vitule, J. R. S., Orsi, M. L., Lima Junior, D. P., Magalhães, A. L. B., ... Agostinho, A. A. (2017). Neotropical freshwater fishes imperilled by unsustainable policies. Fish and Fisheries, 18, 1119-1133.

Piedras, S. R. N., Pouey, J. L. O. F., \& Moraes, P. R. R. (2006). Comportamento alimentar e reprodutivo de peixes exóticos e nativos cultivados na zona sul do Rio Grande do Sul. Revista Brasileira de Agrociência, 12, 341-344.

Pritchard, D. W., Paterson, R. A., Bovy, H. C., \& Barrios-O’Neill, D. (2017). frair: an R package for fitting and comparing consumer functional responses. Methods in Ecology and Evolution, 8, 1528-1534.

R Core Team. (2015). R: a language and environment for statistical computing. Vienna: R Foundation for Statistical Computing. (www.r-project.org/) 
Ricciardi, A., \& Atkinson, S. K. (2004). Distinctiveness magnifies the impact of biological invaders in aquatic ecosystems. Ecology Letters, 7, 781-784.

Ricciardi, A., Hoopes, M., Marchetti, M. P., \& Lockwood, J. L. (2013). Progress toward understanding the ecological impacts of non-native species. Ecological Monographs, 83, 263-282.

Rogers, D. (1972). Random search and insect population models. Journal of Animal Ecology, $41,369-383$.

Rosa, R. S., \& Lima, F. C. T. (2008). Os peixes brasileiros ameaçados de extinção. In A. B. M. Machado, G. M. Drummond, \& A. P. Paglia (Eds), Livro vermelho da fauna Brasileira ameaçada de extinção (pp. 9-278). Belo Horizonte: Fundação Biodiversitas.

Ruesink, J. L. (2005). Global analysis of factors affecting the outcome of freshwater fish introductions. Conservation Biology, 19, 1883-1893.

Salo, P., Korpimäki, E., Banks, P. B., Nordström, M., \& Dickman, C. R. (2007). Alien predators are more dangerous than native predators to prey populations. Proceedings of the Royal Society B, 274, 1237-1243.

Santos, A. F. G. N., García-Berthou, E., Hayashi, C., \& Santos, L. N. (2013). When habitat complexity increases predation risk: experiments with invasive and neotropical native fishes. Marine and Freshwater Research, 64, 752-760.

Sharpe, D. M. T., De León, L. F., González, R., \& Torchin, M. E. (2017). Tropical fish community does not recover 45 years after predator introduction. Ecology, 98, 412-424.

Shephard, S., \& Jackson, D. C. (2005). Channel catfish maturation in Mississippi streams. North American Journal of Fisheries Management, 25, 1467-1475.

Silfvergrip, A. M. C. (1996). A sistematic revision of the neotropical catfish genus Rhamdia (Teleostei, Pimelodidae). Doctoral dissertation, Stockholm University. 156 p.

Simberloff, D. (2003). How much information on population biology is needed to manage introduced species? Conservation Biology, 17, 83-92.

Simberloff, D., Martin, J. L., Genovesi, P., Maris, V., Wardle, D. A., Aronson, J., ... Vilà, M. (2013). Impacts of biological invasions: what's what and the way forward. Trends in 
Simberloff, D., \& Vitule, J. R. S. (2014). A call for an end to calls for the end of invasion biology. Oikos, 123, 408-413.

Sinclair, A. R. E., Pech, R. P., Dickman, C. R., Hik, D., Mahon, P., \& Newsome, A. E. (1998). Predicting effects of predation on conservation of endangered prey. Conservation Biology, 12, 564-575.

Speziale, K. L., Lambertucci, S. A., Carrete, M., \& Tella, J. L. (2012). Dealing with non-native species: what makes the difference in South America? Biological Invasions, 14, 16091621.

Starostka, V. J., \& Nelson, W. R. (1974). Age, growth, sexual maturity, and food of channel catfish in central Lake Oahe, 1968-1969. In Technical papers of the U.S. Fish and Wildlife Service. Washington

Tatarenkov, A., Barreto, F., Winkelman, D. L., \& Avise, J. C. (2006). Genetic monogamy in the channel catfish, Ictalurus punctatus, a species with uniparental nest guarding. Copeia, 2006, 735-741.

Thomaz, S. M., \& Cunha, E. R. (2010). The role of macrophytes in habitat structuring in aquatic ecosystems: methods of measurement, causes and consequences on animal assemblages’ composition and biodiversity. Acta Limnologica Brasiliensia, 22, 218-236.

Townsend, C. R., \& Winterbourn, M. J. (1992). Assessment of the environmental risk posed by an exotic fish: the proposed introduction of channel catfish (Ictalurus punctatus) to New Zealand. Conservation Biology, 6, 273-282.

Troca, D. F. A., \& Vieira, J. P. (2012). Potencial invasor dos peixes não nativos cultivados na região costeira do Rio Grande do Sul, Brasil. Boletim do Instituto de Pesca, 38, 109-120.

Trumpickas, J., Mandrak, N. E., \& Ricciardi, A. (2011). Nearshore fish assemblages associated with introduced predatory fishes in lakes. Aquatic Conservation: Marine and Freshwater Ecosystems, 21, 338-347.

Tyus, H. M., \& Nikirk, N. J. (1990). Abundance, growth, and diet of channel catfish, Ictalurus punctatus, in the Green and Yampa rivers, Colorado and Utah. The Southwestern 
Valentincic, T. B., \& Caprio, J. (1994). Chemical and visual control of feeding and escape behaviors in the channel catfish Ictalurus punctatus. Physiology \& Behavior, 55, 845-855.

Vitousek, P. M., D’Antonio, C., Loope, L. L., \& Westbrooks, R. (1996). Biological invasions as global environmental change. American Scientist, 84, 468-478.

Vitule, J. R. S. (2008). Distribuição, abundância e estrutura populacional de peixes introduzidos no Rio Guaraguaçu, Paranaguá, Paraná, Brasil. Doctoral dissertation, Universidade Federal do Paraná. 143 p.

Vitule, J. R. S., Agostinho, A. A., Azevedo-Santos, V. M., Daga, V. S., Darwall, W. R. T., 599 Fitzgerald, D. B., ... Winemiller, K. O. (2017). We need better understanding about functional diversity and vulnerability of tropical freshwater fishes. Biodiversity and Conservation, 26, 757-762.

602

Vitule, J. R. S., Freire, C. A., \& Simberloff, D. (2009). Introduction of non-native freshwater fish can certainly be bad. Fish and Fisheries, 10, 98-108.

Vitule, J. R. S., Freire, C. A., Vazquez, D. P., Nuñez, M. A., \& Simberloff, D. (2012).

605

606 Revisiting the potential conservation value of non-native species. Conservation Biology,

607 26, 1153-1155.

Vitule, J. R. S., Umbria, S. C., \& Aranha, J. M. R. (2005). Registro de ocorrência do bagre-docanal Ictalurus punctatus (Rafinesque, 1818) em uma importante bacia hidrográfica da

Vucic-Pestic, O., Rall, B. C., Kalinkat, G., \& Brose, U. (2010). Allometric functional response model: body masses constrain interaction strengths. Journal of Animal Ecology, 79, 249Floresta Atlântica paranaense. In I simpósio Brasileiro sobre espécies exóticas invasoras.

Vitule, J. R. S., Umbria, S. C., \& Aranha, J. M. R. (2006). Introduction of the African catfish Clarias gariepinus (Burchell, 1822) into Southern Brazil. Biological Invasions, 8, 677681. (www.mma.gov.br/port/sbf/invasoras/index.cfm) 256.

Welcomme, R. L. (1988). International introductions of inland aquatic species. Rome: FAO 
Fisheries Technical Paper.

619

620

621

622

623

624

625

626

627

628

629

630

631

632

633

634

635

636

637

638

639

640

Wellborn, T. L. (1988). Channel catfish: life history and biology. Southern Regional Aquaculture Center Publication, 180. (srac.tamu.edu/viewCategory/3)

Zanatta, A. S., Ramos, I. P., da Silva, R. J., Langeani, F., \& Carvalho, E. D. (2010). Pisces, Siluriformes, Ictaluridae, Ictalurus punctatus (Rafinesque, 1818): first record in middle Paranapanema river reservoir, aquaculture and exotic species dispersion. Check List, 6, 589-591.

\section{Figure legend}

Figure 1. Type II Functional Response curves for channel catfish Ictalurus punctatus (dashed line) and South American silver catfish Rhamdia quelen (solid line) preying on blue tetra Mimagoniates microlepis. Points indicate mean consumption per density. Shading represents bootstrapped $(n=2000)$ 95\% confidence intervals for each species.

\section{Assessing the impacts of the channel catfish Ictalurus punctatus using the}

\section{Comparative Functional Response approach}

Table S1. Field data on total abundance (n), capture per unit effort (CPUE) and total biomass (in grams) of channel catfish Ictalurus punctatus and South American silver catfish Rhamdia quelen captured in 17 standardised samples, between 2005 and 2007, using different fishing gears. Data from Vitule (2008). Long lines were of $10 \mathrm{~m}$ length, and gill nets were of $30 \times 1.70 \mathrm{~m}$, with exposure times in all cases being 1500 hours. 


\section{Ictalurus punctatus}

\begin{tabular}{|c|c|c|c|c|}
\hline Longline & $\begin{array}{l}3 \text { longlines with } 10 \text { fish } \\
\text { hooks }\end{array}$ & 8 & $\begin{array}{l}0.0001 \\
78\end{array}$ & 9312 \\
\hline Gill net (20 mm) & Gill net & 5 & $\begin{array}{l}6.54 \mathrm{E}- \\
05\end{array}$ & 1069 \\
\hline Gill net (40 mm) & Gill net & 4 & $\begin{array}{l}5.23 E- \\
05\end{array}$ & 2075 \\
\hline Gill net (60 mm) & Gill net & 1 & $\begin{array}{l}1.31 \mathrm{E}- \\
05\end{array}$ & 740 \\
\hline Fishing rod & 4 anglers, $\approx 60 \mathrm{~h}$ & $\begin{array}{l}1 \\
2\end{array}$ & 0.05 & 14496 \\
\hline
\end{tabular}

\section{Rhamdia}

quelen

$\begin{array}{llllr}\text { Longline } & \begin{array}{l}\text { 3 longlines with 10 fish } \\ \text { hooks }\end{array} & 4 & 0.0008 & 14106 \\ & & 0 & 89 & \\ \text { Gill net }(20 \mathrm{~m}) & \text { Gill net } & 3 & 0.0004 & 8133 \\ & & 1 & 05 & \\ \text { Gill net }(40 \mathrm{~mm}) & \text { Gill net } & 3 & 0.0004 & 14768 \\ & & 3 & 31 & \\ \text { Fishing rod } & 4 \text { anglers, } \approx 60 \mathrm{~h} & 8 & 0.0333 & 1978 \\ & & & 33 & \end{array}$

641 